Urologia

Internationalis

\section{Review}

Urol Int 2020;104:501-509

DOI: $10.1159 / 000506235$

\section{Nils Hansson ${ }^{a}$ \\ Matthis Krischel ${ }^{a}$ \\ Per Södersten ${ }^{b}$ \\ Friedrich H. Molla \\ Heiner Fangerau ${ }^{a}$}

a Department for the History, Philosophy, and Ethics of Medicine, Faculty of Medicine, Heinrich Heine University Düsseldorf, Düsseldorf, Germany; ${ }^{\text {b Department of }}$ Neurobiology, Care Sciences, and Society, Karolinska Institutet, Novum, Huddinge, Sweden

\title{
"He Gave Us the Cornerstone of Sexual Medicine": A Nobel Plan but No Nobel Prize for Eugen Steinach
}

\section{Keywords}

History of medicine · Urology · Endocrinology · Sexology . Nobel Prize · Eugen Steinach

\begin{abstract}
This paper reviews the files in the archive of the Nobel Prize Committee for Physiology or Medicine on the Austrian physiologist and pioneering researcher in the emerging fields of urology and sexual medicine: Eugen Steinach (1861-1944). It reconstructs and analyzes why and by whom Steinach was nominated for the Nobel Prize between 1920 and 1938 and discusses the reasons why he never received the award, although the Nobel Committee judged him as prizeworthy. Steinach's Nobel nominee career is extraordinary - not only because of his strong support by renowned international nominators from different scientific and medical disciplines, but also because of the controversial discussions within the Nobel Committee on his achievements, colored by the debates in the international scientific community. The Nobel Prize story adds a new perspective on how contemporary international scholars evaluated Steinach's research on reproduction, "male-making" females, "female-making" males, homosexuality, and the concept of rejuvenation.
\end{abstract}

(c) 2020 The Author(s)

Published by S. Karger AG, Basel

karger@karger.com www.karger.com/uin

Karger"
(C) 2020 The Author(s)

Published by S. Karger AG, Basel

Karge

Open access

This is an Open Access article licensed under the Creative Commons Attribution-NonCommercial-4.0 International License (CC BY-NC) (http://www.karger.com/Services/OpenAccessLicense), applicable to the online version of the article only. Usage and distribution for commercial purposes requires written permission.

\section{Introduction}

Much has been written about Eugen Steinach (18611944), the Austrian physiologist and pioneering researcher in the emerging fields of urology, endocrinology, and sexual medicine [1-4]. His character, his career, and his scientific work aroused general attention during his lifetime and well beyond, ranging from voyeuristic sensation seeking to the direct translation from research to clinical application. The historian Florian Mildenberger has identified rejuvenation and working towards a "cure" for homosexuality as Steinach's central fields of research [5]. While these two potential practical applications of his work received much public attention during Steinach's lifetime, his discoveries of hormone action on the brain were pioneering and went unnoticed for 7 decades. And so, in making Steinach a "spectacular (scientific) failure in interwar Vienna," Cheryl Logan [6] referred to the sensationalist aspects of his work, whilst recognizing the significance of his basic research program on reproductive physiology, which was a cornerstone in the establishment of the birth control pill. His work on gonad transplantation and his conclusions about sex development take the central position in this account. His research on "inner secretions" (i.e., hormones) was considered the biological

Nils Hansson, $\mathrm{PhD}$

Department for the History, Philosophy, and Ethics of Medicine, Faculty of Medicine Heinrich-Heine-Universität Düsseldorf, Universitätsstrasse 1

DE-40225 Düsseldorf (Germany) nils.hansson@hhu.de 
Table 1. Nobel Prize nominations for Eugen Steinach

\begin{tabular}{|c|c|c|}
\hline $\begin{array}{l}\text { Year of } \\
\text { nomination }\end{array}$ & Nominator & Motivation \\
\hline 1920 & W. Roux, Germany & Transplantation of gonads \\
\hline 1921 & J.H. Zaaijer, The Netherlands & Work on the functions of the reproductive glands \\
\hline 1922 & Y. Sakaki, Japan & $\begin{array}{l}\text { Work on transplantation of reproductive glands and particularly on } \\
\text { rejuvenation ("Verjüngungskunst") }\end{array}$ \\
\hline 1927 & L. Haberlandt, Austria & Numerous studies on the endocrine function of the reproductive glands \\
\hline 1930 & H.H. Meyer, Germany/Austria & $\begin{array}{l}\text { Work on the effect of the reproductive glands on functions of the } \\
\text { body and soul }\end{array}$ \\
\hline 1930 & E.P. Pick, Austria & $\begin{array}{l}\text { Work on the physiology of the reproductive glands, in particular their } \\
\text { endocrine function and its relation to the organism }\end{array}$ \\
\hline 1930 & S. Klein, Austria & $\begin{array}{l}\text { Work on the physiology of the reproductive glands, in particular their } \\
\text { endocrine function and its relation to the whole organism }\end{array}$ \\
\hline 1934 & A. Durig, Austria & Work on sexual hormones, therapeutic use of gonadotropic hormones \\
\hline 1938 & $\begin{array}{l}\text { J.C. Bock, A.S. Jensen, T. Madsen, } \\
\text { P. Boysen Jensen, E. Lundsgaard, and } \\
\text { K. Sand, Denmark }\end{array}$ & Work on biology, especially the bipotentiality of the sexes \\
\hline
\end{tabular}

basis of the development of sex and sexuality. The historian Sonja Walch [7] placed Steinach's work in the context of early-20th-century physiological research in connection with the pharmaceutical industry. Emphasizing the material and epistemic aspects of the experimental cultures leading Steinach to formulate his ideas of sex hormones, Walch [8] identified how he redefined the boundaries between sex, homosexuality, and rejuvenation during the first half of the 20th century.

Because Steinach was such a renowned scientist, it is no surprise that some authors also reasoned about Steinach's chances to be awarded the Nobel Prize $[9,10]$. In fact, Steinach himself considered himself to be a worthy candidate, as a personal letter from Steinach to the German-American endocrinologist Harry Benjamin (18851986) in 1939 indicates:

Only after the hype concerning rejuvenation, sexual hormones appeared lucrative to the chemists. The big propaganda by the fat cats was permissible and has just now been rewarded with the Nobel Prize (Butenandt, Ruzicka). In 1912, I was first nominated for the Nobel prize from the University of Halle (Wilhelm Roux). At that time, those boys were still going to school. Since then, I have been proposed about 14 times from all sides. Most recently from the University of Copenhagen. Now the lucky exploiters of my work and discoveries have received the prize for "sexual research" (Stoff [11]).
By that time, the 78-year-old Steinach lived as a refugee in Switzerland. After the incorporation of Austria in the National Socialist German Empire in 1938, Steinach's laboratory at the BVA (Biologische Versuchsanstalt) in Vienna and the BVA itself had been put under the management of the National Socialist party member Franz Köck. The founder and former director Hans Przibram (1874-1944), Steinach, and other members of the BVA were considered "Jewish" and denied access [12].

Steinach was nominated for the Nobel Prize in Physiology or Medicine at least 9 times between 1920 and 1938 (Table 1). We will examine who nominated Steinach and for what reason in an attempt to explain why he never received the prize. Our sources are the Nobel Committee evaluations and nominations (written in Swedish, German, Danish, or English) gathered at the archive of the Nobel Committee for Physiology or Medicine in Sweden, other archival sources, and a review of secondary literature.

\section{A Biographical Note}

Eugen Steinach was born in 1861 into a Jewish family in Hohenems (Vorarlberg) in the Austrian-Hungarian Empire. He studied chemistry, zoology, and medicine in 


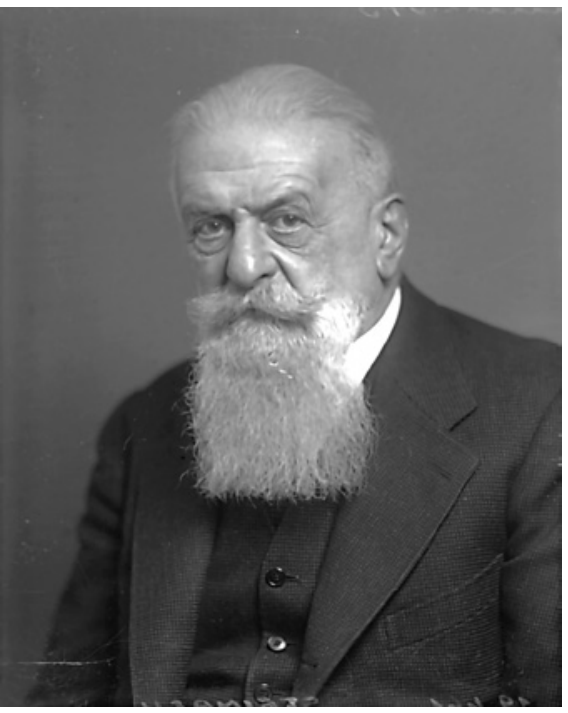

Fig. 1. Eugen Steinach (1861-1944), glass plate. Reproduced with permission from the Austrian National Library (ÖNB) (Picture Archives and Graphics Department, No. 222543B).

Geneva [13], Vienna, and Innsbruck. He received his MD in 1886 and subsequently joined the laboratory of the physiologist Karl Ewald Hering (1834-1918) at the Charles Ferdinand University in Prague, where he received his Habilitation in 1890. Five years later, he was appointed extraordinary professor and in 1907 ordinary professor. In 1912, Steinach moved to Vienna and became Head of the Department for Animal Physiology at Vienna's Experimental Biological Institute of the Academy of Sciences (Vivarium). During the following years, he published several studies on the experimental transplantation of the sex glands of animals. His experiments showed that the sexual development in mammals was not rigidly controlled by heredity or by sperms and eggs, but unfolded flexibly under the influence of hormones [14]. This led him to discuss the possibility of "curing" homosexuality via surgery by transplantation of testicles $[15,16]$. The first test subject, a young man who had to have his testicles removed because of tuberculosis in 1916, was apparently so successfully "cured" from his condition of homosexuality that "in the spring of 1917 , he fell in love (with a woman) and got engaged; in June of that year, he got married." [17]

Not least because it challenged the boundaries between masculinity and femininity, Steinach's hormone theory was under discussion early on $[18,19]$, and

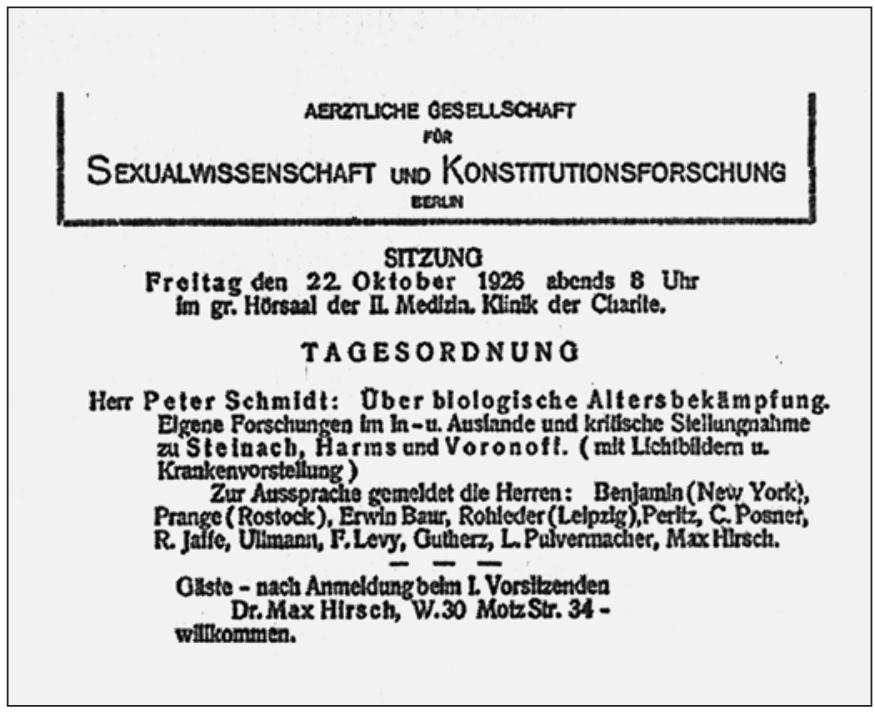

Fig. 2. Announcement of the presentation of Steinach's research at the Charité Hospital, Berlin, by AeGeSe (Ärztliche Gesellschaft für Sexualmedizin und Eugenik), which was accompanied by the famous German urologist C. Posner (1854-1928) of Berlin and Hermann Rohleder (1866-1934) of Leipzig, Moll Collection (Rohleder files), Repro Keyn, with permission.

Steinach gained a strong international reputation [20, 21]. For instance, he received the Ignaz L. Lieben prize of the Austrian Academy of Science twice [22], and in 1919 he was awarded a doctor honoris causa of the University of Rostock, Germany [23]. His name became verbal, "to steinach" meaning a vasoligation or unilateral vasectomy as a rejuvenating procedure. Contemporary compendia were filled with reports about the famous operation or the announcement of visits to the United States [24-27]. As historian Chandak Sengoopta [28] pointed out, "newspapers were full of gossipy accounts of Steinach operations performed on aging millionaires," and allegedly successful operations were reported from Europe, the United States, Asia, and South America.

One of the famous patients who underwent the vasoligation operation was Sigmund Freud (1856-1939), who was operated by urologist Victor Blum (1877-1954) in 1923. After the procedure, Freud was ambiguous about its effect [29].

At the beginning of the 1920s, a scientific and popular movie was produced to inform science and public about Steinach's research and outcome (Fig. 1, 2) [30].

In 1932, Eugen Steinach retired. After the "Anschluss" (annexation) of Austria to Germany in 1938, he was forced to exile to Zürich, where he remained for 


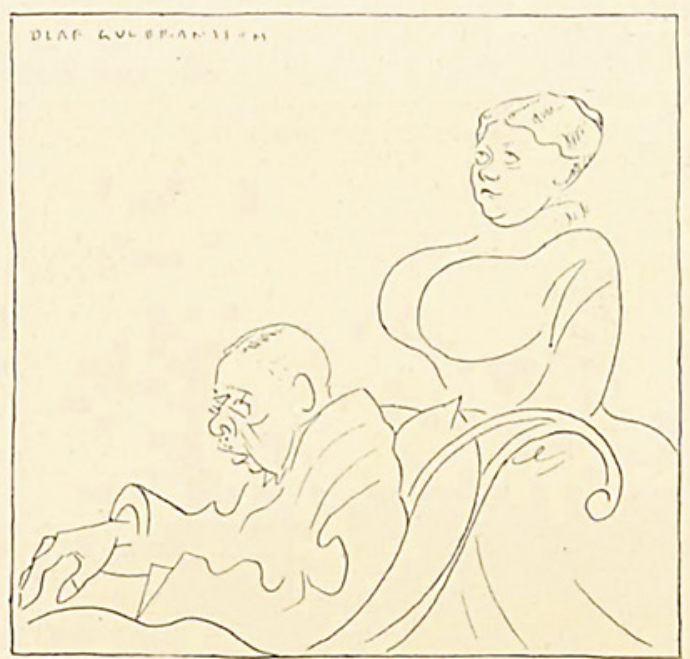

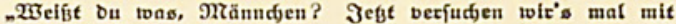
Wrofefior Steinatj."

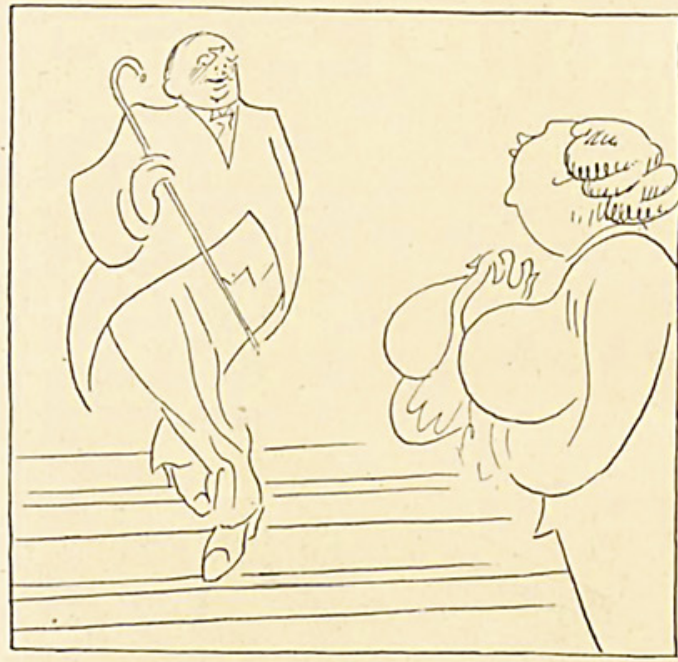

-3a, ift, es benn mőgtid, 210olf !-

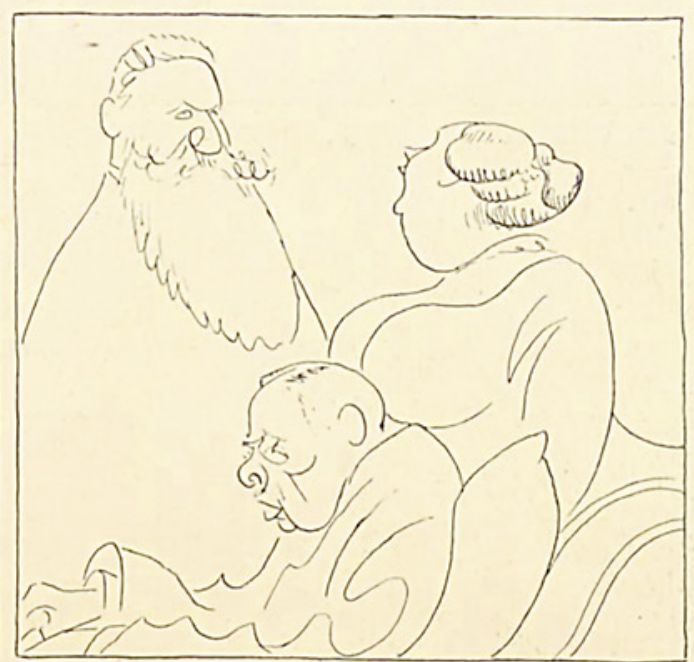

- Suten Tag, \$err Profe斤or !"

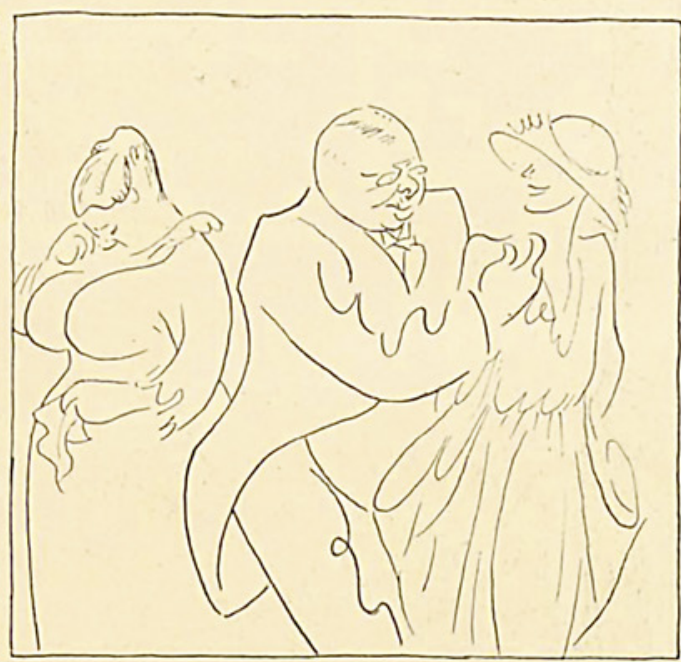

-D, lef̧t lift alles mőglid)!*

Fig. 3. "When he came back": caricature of Olaf Gulbransson (1873-1958). German satiric paper Simplicissimus, 1920, August 18, p. 200.

the rest of his life in an unsecure position, because the Schering Company in Berlin has blocked all his annuities. He died in Territet near Montreux (Switzerland) in 1944 after unsuccessful attempts to immigrate to the USA (Fig. 3, 4) [31].

\section{Glimpses behind Closed Doors: Why and by Whom Was Steinach Nominated for the Nobel Prize?}

The first nomination for Eugen Steinach was submitted in 1920 by the German anatomist and embryologist Wilhelm Roux (1850-1924), whom Steinach later de- 


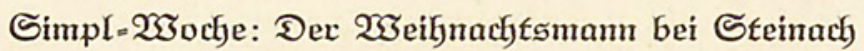

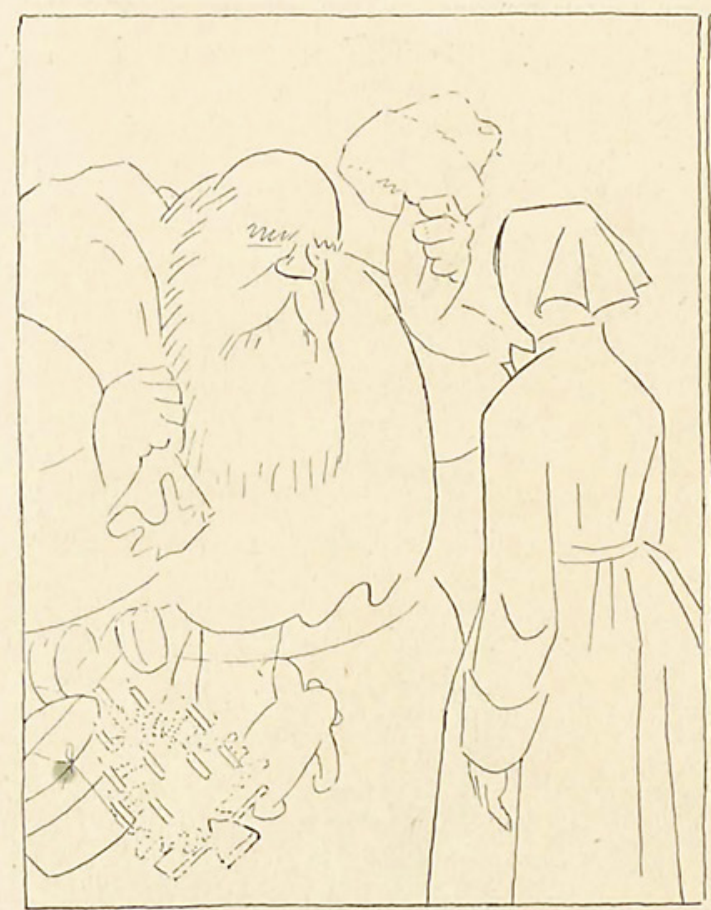

"3in id) bier redt bei Profefior Gteinad?"

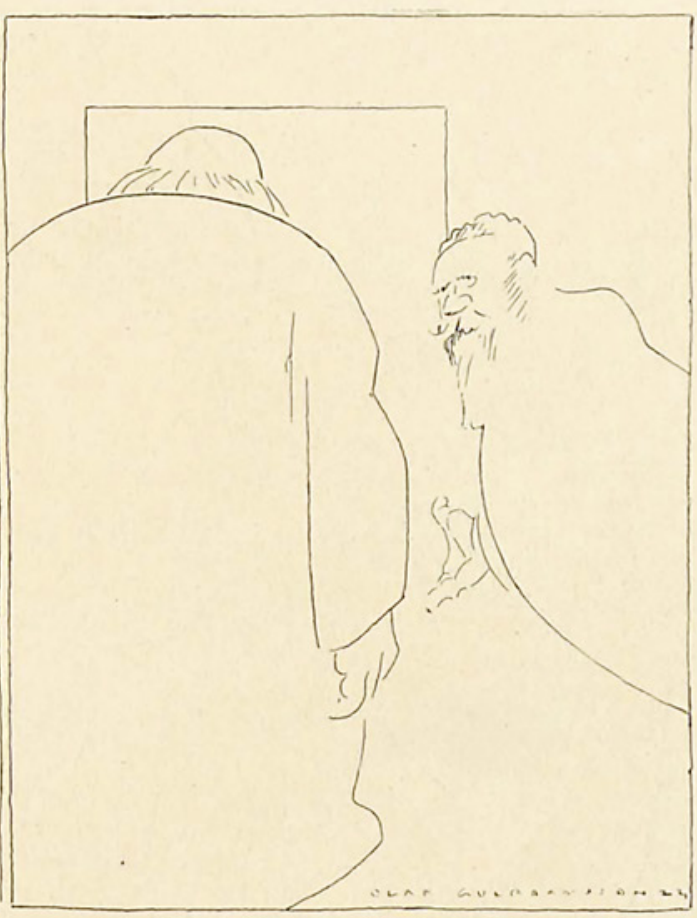

„Tein 2Bort, alter Mann - id) weiß, was Gie wollen!"
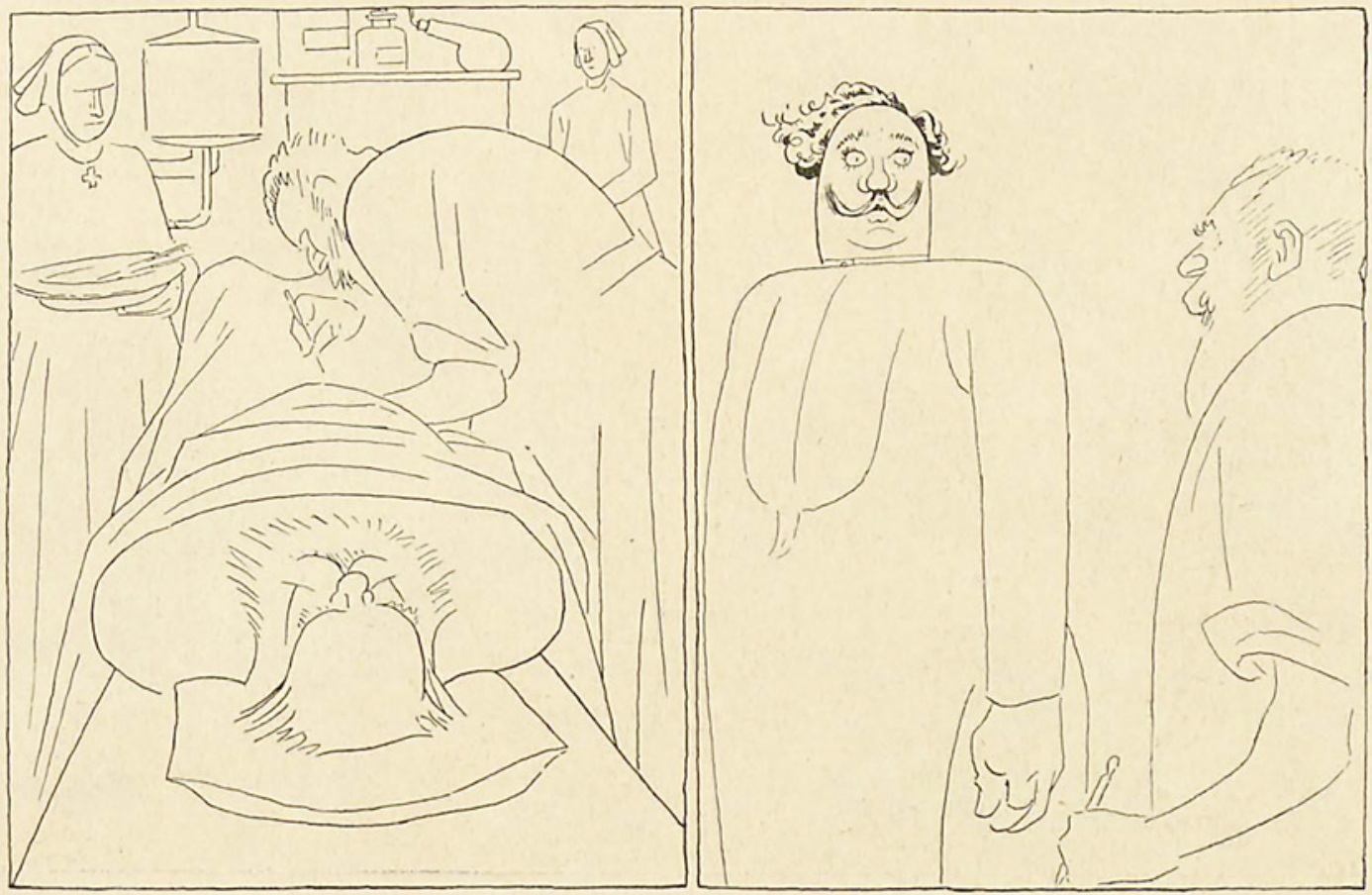

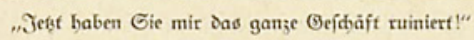

Fig. 4. "Santa Claus meets Steinach”: caricature of Olaf Gulbransson. German Satiric paper Simplicissimus, 1927, December 26. 
scribed as a "master of the researches in developmental mechanics" [32]. Roux [33], who in the same year had published positive remarks about Steinach's research, argued in his nomination letter that Steinach by means of transplanting female and male gonads had uncovered mechanisms of the sexual behavior in animals and humans, an approach that could prevent "the unnatural, homosexual sex drive" [34]. The nomination letter was submitted after the nomination deadline and did not lead to a written evaluation by the Nobel Committee. The next year, Steinach was put forward by the Dutch physician Johannes Henricus Zaaijer (1876-1932), "habilitated" in urology and surgery, who, again, emphasized Steinach's transplantations that explored gonadal physiology and sexual behavior, also stating that a "puberty gland transplantation" could "cure" homosexuality. Zaaijer added that the "culmination" of Steinach's research was the theory of rejuvenation, which he had demonstrated on rats. Still, some questions remained to be answered:

But will it also work on humans? We do not know for sure. Should we hope for it or fear it? We don't know yet. But we do know that Steinach has given us new insights that have opened up many opportunities. [35]

In 1921, Steinach was taken up for the evaluation as Nobel Prize candidate and reviewed by the physiologist Johan Erik Johansson (1862-1938) and the surgeon Jules Åkerman (1861-1951). While Johansson highly valued Steinach's techniques of transplanting testicles and ovaries, he argued that his hypotheses on the existence of a "puberty gland," the "cure of homosexuality," and "the rejuvenation concept" would need to be verified by other scholars before his prize-worthiness could be fully evaluated. Also, Johansson was careful not to get carried away by Steinach's reputation: “As it stands, Steinach seems to get easily convinced by his own research when it gets much attention by the public" [36]. Next to this wait-andsee approach, Åkerman focused on surgical aspects of Steinach's research, concluding that he could not find any reason to promote him. However, that was not the only negative outcome in the Nobel Committee discussions that year. No Nobel Prize in Physiology or Medicine was awarded in 1921 (one of few exceptions if we disregard the war years 1915-1918 and 1940-1942).

We need to consider that the debate on homosexuality was contentious in Steinach's days. The release of Richard Oswald and Magnus Hirschfeld's "Anders als die Andern" in 1919, the first pro-gay film to fight Germany's Paragraph 175 within the penalty laws, which made homosexuality illegal, was courageous by all measures. In the film, Hirschfeld, himself a homosexual physician, refers to Steinach's work in support for homosexuality as a normal human trait. The film was banned shortly after delivery in 1920, and it took until 1969 before homosexuality was no longer illegal in Germany.

Without knowing that it had been requested in the 1921 Nobel Committee evaluations, the Austrian physiologist Ludwig Haberlandt (1885-1932) underlined in his 1927 nomination that many international scholars had confirmed Steinach's male making by testicular transplantation, which together, in his view, were precursors for the above-mentioned "Steinach procedure" ("an operation celebrated by international physicians") [37]. However, the nomination did not motivate a new committee evaluation.

In 1930, Steinach was proposed in 3 separate nominations by a trio of Viennese professors: the German pharmacologist Hans Horst Meyer (1853-1939), his successor as chair of pharmacology at the University of Vienna Ernst Peter Pick (1872-1960), and the ophthalmologist Salomon Klein (1845-1937). Salomon Klein pointed out that Steinach had managed to combine theoretical hypotheses with practical experiments; the rejuvenation research was particularly impressive:

[I]t has travelled around Europe and beyond [...] at first there were some sceptical voices, but this ingenious therapy is now widely acknowledged, it is a true "egg of Columbus" in science. [38]

The competitive Viennese nominations led to new negotiations about Steinach in the Nobel Committee. The pharmacologist Göran Liljestrand (1886-1968), secretary of the Nobel Committee, completed a 12-page evaluation stating that Steinach's work had "immense theoretical interest," both "impressive" and "logical" and marked by "great originality" [39]. Although its practical significance was not yet clear, Liljestrand did not hesitate to say that Steinach "well deserves" a Nobel Prize [40]. However, the jury finally chose Steinach's short-list rival from 1921 Karl Landsteiner "for his discovery of human blood groups."

Two further nominations of Steinach were submitted in the subsequent years: In 1934, the Austrian physiologist Arnold Durig (1872-1961) nominated him. In 1938, six Danes nominated him jointly: the pharmacologist John C. Bock, the zoologist Adolf S. Jensen (1866-1953), the bacteriologist Theodor Madsen (1870-1957), the plant physiologist Peter Boysen Jensen (1883-1959), the physiologist Ejnar Lundsgaard (1899-1968), the biologist Øjvind Winge (1886-1964), and the reproductive biologist and professor of forensic medicine Knud Sand (18871968). Sand, an expert on the endocrinology of the sexes, 
was strongly influenced by Steinach as he had tried to show a causality between gonadal function and sexual orientation, leading to experiments with testicle transplantation on homosexual men [41]. Their relationship was marked by mutual respect: While Sand considered Steinach's gonadal transplants to be the method that "placed all others in the shadows" [42], Steinach regarded Sand as "an acknowledged pioneer in all that relates to experimental hermaphroditism" [43].

The Danish sextet argued that in particular Steinach's work on the bipotentiality "through transformations of the sexes and therewith connected phenomenons" was prizeworthy, and that a detailed motivation would not be necessary since his research "is so famous around the globe." The nominators further stated that Steinach's papers in sexual biology (on monosexuality, bisexuality, experimental hermaphroditism, and bipotentiality) had provided the "cornerstone" for the entire scientific discipline of sexual medicine. By now (1938), they added, his research had been widely accepted within the scientific community by both basic researchers and clinicians:

The group of opponents decrease steadily... Steinach will doubtless always be a leading character in the field of sexual biology and in the domain of endocrine secretion [44].

This nomination contributed to a last Nobel Committee evaluation of Steinach by Göran Liljestrand. Summarizing the evaluations in 1921 and 1930, Liljestrand put all previous doubts of the validity of some of Steinach's research on basic endocrinology aside, concluding that his hypotheses had been "verified to a large extent." The only exception was his rejuvenation theory "or rather endocrine regeneration," as he preferred to phrase it, which still attracted critics. Liljestrand concluded:

With regard to the question if Steinach's studies are considered prize-worthy, I still believe they are, in particular the work on the bipotentiality of the sexes. However, the committee found him prize-worthy in 1930 as well, and neither any new facts have been presented nor have Steinach's achievements reached new heights during the eight years that have passed. Because of his now dated work there are in my opinion no justified reasons to award him the Nobel Prize [45].

Finally, the 1938 Nobel Prize was awarded to the Belgian physiologist Corneille Heymans (1892-1968) "for the discovery of the role played by the sinus and aortic mechanisms in the regulation of respiration." But this was not the last time Liljestrand commented on the topic. Reviewing the history of the Nobel Prize in Physiology or Medicine in 1962, he mentioned that Steinach, who had passed away in 1944, had been a prime candidate (Table 1):

Eugen Steinach
$[\mathrm{H}]$ is attempts to bring about a restoration or regeneration of ageing organisms by increasing the internal secretion of the sex glands [...] were partly successful, though the extensive publicity they received and for which Steinach himself was probably not responsible placed them in an unfavourable light [46].

\section{Discussion}

\section{Eugen Steinach's Legacy}

Steinach's rejuvenation concept urged celebrities to get "steinached" [47, 48], such as the 1923 Nobel Prize laureate in literature William Butler Yeats (1865-1939). "It revived my creative power and...sexual desire," he wrote in 1937. Roughly at the same time, the JAMA editor Morris Fishbein (1889-1976) degradingly brought up the procedure in his book "The Medical Follies" [49] and stated:

...Today, no other phase of therapeutics is subject to more abuse and fantastic exploitation...The hope of restoring youth is such an impelling motive that even the prospect of surgical intervention does not seem to dampen the enthusiasm of those, who are willing to grasp at such new suggestions toward accomplishing an invigorating end [29].

Fishbein denounced the Steinach procedure as early as 1927 with the lack of scientifically controlled studies.

In 1969, the Simon Population Trust, a voluntary sterilization organization in the UK, declared that the Trust did not recommend vasectomy for rejuvenation. Although he never received the award, Steinach's candidacy is extraordinary not only because of the support by wellknown international nominators representing different scientific and medical disciplines, but also because of the contentious discussions within the Nobel Committee on his achievements, colored by the debates in the international scientific community. In 1938, Nobel Committee member Göran Liljestrand pointed out that Steinach's work had "immense theoretical interest" and "great originality," but that Steinach was too old for receiving the prize. Four decades later, Frank Beach [50] noted that Steinach's ideas were ahead of his time and that "their final test was delayed for half a century". For example, Steinach's discovery of the role of estrogen formation in the brain for the sexual behavior of males [51] hibernated as a "sleeping beauty" $[52,53]$.

Thus, timing was, and still is, important in a Nobel context. Steinach said the right thing at the wrong time, and this may, paradoxically, explain why he was not rewarded the Nobel Prize. Moreover, sensationalist journalism contributed in distracting from the significance of 
his contributions, or as Harry Benjamin put it in his obituary for Steinach:

In the medical profession he was soon praised as a genius by some and condemned as a quack by others, while the laity saw in him a modern Ponce de Leon on the one hand and a violator of sacred laws of nature and morality on the other [54].

\section{Acknowledgments}

Access to the files in the Nobel Archive was kindly provided by the Nobel Committee for Physiology or Medicine, Medicinska Nobelinstitutet, Nobels Väg 1, Solna, Sweden (all translations by the authors).

\section{Disclosure Statement}

The authors have no conflicts of interest to declare.

\section{Funding Sources}

None.

\section{Author Contributions}

All authors have made substantial contributions to the conception and design of the study. The first draft was made by N.H. All authors have revised the manuscript critically.

\section{References}

1 Benjamin H. Eugen Steinach, 1861-1944: A life of research. Sci Mon. 1945;61:427-42.

2 Harms E. Forty-four years of correspondence between Eugen Steinach and Harry Benjamin. A valuable addition to the Manuscript Collection of The Library of The New York Academy of Medicine. Bull N Y Acad Med. 1969;45(8):761-6.

3 Schultheiss D, Denil J, Jonas U. Rejuvenation in the early 20th century. Andrologia. 1997 Nov-Dec;29(6):351-5.

4 Stoff H. Ewige Jugend. Konzepte der Verjüngung vom späten 19. Jahrhundert bis ins Dritte Reich. Köln: Böhlau; 2004. p. 34.

5 Mildenberger F. Verjüngung und "Heilung" der Homosexualität. Eugen Steinach in seiner Zeit. Z Sexualforsch. 2002;15(4):302-22.

6 Logan C. Hormones, heredity and race. Spectacular failure in interwar Vienna. New Brunswick: Rutgers University Press; 2013. pp. 37-8.

7 Walch S. Triebe, Reize, Signale. Eugen Steinachs Physiologie der Sexualhormone. Vom biologischen Konzept zum Pharmapräparat, 1894-1938. Wien: Böhlau; 2016. p. 14.

8 Walch S. Triebe, Reize, Signale. Eugen Steinachs Physiologie der Sexualhormone. Vom biologischen Konzept zum Pharmapräparat, 1894-1938. Wien: Böhlau; 2016. pp. 96-121.

9 Södersten P. Steinach and Young, Discoverers of the Effects of Estrogen on Male Sexual Behavior and the "Male Brain". eNeuro 2015; $17 ; 2(6)$.

10 Södersten P, Crews D, Logan C, Soukup RW. Eugen Steinach: the first neuroendocrinologist. Endocrinology. 2014 Mar;155(3):68895.

11 Stoff H. Ewige Jugend. Konzepte der Verjüngung vom späten 19. Jahrhundert bis ins Dritte Reich. Köln: Böhlau; 2004. p. 50.

12 Müller GB, editor. Vivarium. Experimental, quantitative, and theoretical biology at Vienna's Biologische Versuchsanstalt. Cambridge, MA: MIT Press; 2017.
13 Personalakte Steinach. Curriculum vitae. Prag: Archiv der Deutschen Karls-FerdinandUniversität

14 Logan C. Hormones, Heredity and Race. Spectacular Failure in Interwar Vienna. New Bruinswick: Rutgers University Press; 2013. p. 7.

15 Lichtenstern R. Mit Erfolg ausgeführte Hodentransplantation am Menschen. Münch Med Wschr. 1916;63:663-5.

16 Schlich T. Die Erfindung der Organtransplantation. Erfolg und Scheitern des chirurgischen Organersatzes (1880-1930). Frankfurt/New York: Campus; 1998. pp. 159-60.

17 Steinach E, Lichtenstern R. Umstimmung der Homosexualität durch Austausch der Pubertätsdrüsen. Münch Med Wochenschr. 1918; 65:165-8

18 Romeis B. Untersuchung zur Verjüngungshypothese Steinachs. Münch Med Wochenschr. 1921;68:6003.

19 Romeis B. Altern und Verjüngung. In: Hirsch M. Handbuch der inneren Sekretion. Eine umfassende Darstellung der Anatomie, Physiologie und Pathologie der endokrinen Drüsen. Band 2, Teil 2. Leipzig: Curt Kabitsch; 1931. pp. 1833, 1853-1855.

20 Schmidt P. The theory and practice of the Steinach operation. With a report on one hundred cases [translated from German by M.D. Eder] and an introduction to the English edited by J. Johnston Abraham. London: Heineman; 1924.

21 Kammerer P. Rejuvenation and the prolongation of human efficiency: experiences with the Steinach-operation on man and animals. London: Methuen; 1924.

22 Soukoup W. Die wissenschaftliche Welt von gestern. Die Träger des Ignaz L. Lieben Preises 1865-1937 und des Richard Lieben Preises 1912-1928. Wien: Böhlau; 2004.

23 Universitätsarchiv Rostock 2.01.3, 2-1919: Ehrenpromotionen 1919.
24 Krischel M, Hansson N. Ageing: rejuvenation study stirs old memories. Nature. 2017 May; 546(7656):33.

25 Hirschfeld M. Künstliche Verjüngung. Künstliche Geschlechtsumwandlung. Die Entdeckung Prof. Steinachs und ihre Bedeutung. Berlin: Johndorff; 1920.

26 Dr. Steinach Coming to Make Old Young; Vienna Discoverer of Method to "Retard Senility" Invited to Visit America. MANY UNDERGO OPERATIONS Dr. Lorenz, Famous Surgeon, Said to Have Been Rejuvenated by Treatment. New York Times. 1922, February 9.

27 Haire N. Rejuvenation: The work of Steinach, Voronoff, and others. London: George Allen \& Unwin Ltd.; 1925.

28 Sengoopta C. 'Dr Steinach coming to make old young!': sex glands, vasectomy and the quest for rejuvenation in the roaring twenties. Endeavour. 2003;27(3):122-6.

29 Nanninga JB. The Gland Illusion: Early Attempts at Rejuvenation through Male Hormone Therapy. NC: Mc Farland Jefferson; 2017. p. 89.

30 Bonah C, Zimmer A. Le calvaire du SteinachFilm (1922-23). Représentations du médecin dans le film de recherche et d'enseignement médical. Soc Rep. 2009;2(28), p. 87-105.

31 Benjamin H. The late Eugen Steinach. New York Times. 1944, June 3. p. 12

32 Steinach S, Loebel J. Sex \& Life. London: Faber \& Faber; 1940. p. 165.

33 Roux W. Zur Verjüngunsmethode Steinachs. Dtsch Med Wochenschr. 1920;46:891.

34 Nobel Committee yearbook 1920, Roux.

35 Nobel Committee yearbook 1921, Zaaijer.

36 Nobel Committee yearbook 1921, evaluation Johansson.

37 Nobel Committee yearbook 1927, Haberlandt.

38 Nobel Committee yearbook 1930, Klein.

39 Nobel Committee yearbook 1930, evaluation Liljestrand. 
40 Nobel Committee yearbook 1930, evaluation Liljestrand.

41 Sand K. Vasektomie beim Hunde als Regenerationsexperiment. Wien Med Wochenschr. 1922;72:1315-9.

42 Logan CA. Overheated rats, race, and the double gland: Paul Kammerer, endocrinology and the problem of somatic induction. J Hist Biol. 2007;40:683-725, 689.

43 Steinach S, Loebel J. Sex \& Life. London: Faber \& Faber; 1940. p. 93.

44 Nobel Committee yearbook 1938, Danish joint nomination for Steinach.

45 Nobel Committee yearbook 1938, evaluation Liljestrand.
46 Liljestrand G. The Prize in Physiology or Medicine. In: Schück H, Sohlman R, Österling A, Liljestrand G, Westgren A, Siegbahn $\mathrm{M}$, et al, editors. Nobel, the man and his prize. 2nd ed. New York: Elsevier; 1962. pp. 131343, 224.

47 Steinach E. Rejuvenation through the experimental revitalization of the aging puberty gland. Berlin: Springer; 1920.

48 Wyndham D. Versemaking and lovemaking-W. B. Yeats' "strange second puberty": norman Haire and the Steinach rejuvenation operation. J Hist Behav Sci. 2003;39(1):25-50.

49 Fishbein M. The medical follies. New York: Boni \& Liveright; 1925.

50 Beach FA. Historical origins of modern research on hormones and behavior. Horm Behav. 1981 Dec;15(4):325-76.
51 Steinach E, Kun H, Peczenik O. Beiträge zur Analyse der Sexualhormonwirkung. Tierexperimentelle und klinische Untersuchungen. Wien Klin Wochenschr. 1936;49:899-903.

$52 \mathrm{Ke}$ Q, Ferrara E, Radicchi F, Flammini A. Defining and identifying Sleeping Beauties in science. Proc Natl Acad Sci USA. 2015 Jun; 112(24):7426-31.

53 Södersten P. A historical and personal perspective on the aromatization revolution: Steinach confirmed. In: Balthazart J, Ball GF, editors. Brain aromatase, estrogens, and behavior. New York: Oxford University Press; 2012. pp. 281-314.

54 Benjamin H. Eugen Steinach, 1861-1944: A Life of Research. Sci Mon. 1945;61(6): $427-$ 42,434 . 